\title{
PENGEMBANGAN $E$-MODUL AKUNTANSI KOMPETENSI DASAR MENCATAT TRANSAKSI DALAM PERSAMAAN DASAR AKUNTANSI DI SEKOLAH MENENGAH KEJURUAN
}

\author{
Oleh: Hendri Gunawan \\ jayasampurna85@gmail.com \\ (Program Studi Pendidikan Akuntansi, FKIP Universitas PGRI Palembang)
}

\begin{abstract}
Abstrak-Penelitian ini bertujuan untuk menghasilkan bahan ajar e-Modul Akuntansi kompetensi dasar mencatat transaksi dalam persamaan dasar akuntansi di Sekolah Menengah Kejuruan di Palembang yang valid dan praktis, serta untuk mengetahui efek potensialnya terhadap hasil belajar peserta didik. Metode peneltian yang digunakan adalah metode penelitian pengembangan (development research) dengan model pengembangan produk Rowntree Model, sedangkan evaluasi produk menggunakan evaluasi formatif model Tessmer. Berdasarkan penelitian pengembangan ini, bahan ajar yang dikembangkan telah memenuhi kriteria valid, praktis dan memiliki potensial efek, dalam hal ini pada peserta didik kualitas hasil belajarnya sangat baik dan keaktifannya sangat tinggi dalam setiap pertemuan. Saran guru, dapat menjadikan bahan ajar ini sebagai inovasi baru dalam proses pembelajaran untuk dapat meningkatkan pemahaman dan hasil belajar siswa; sekolah, agar dapat meningkatkan fasilitas laboratorium dan memfasilitasi guru agar dapat mengembangkan bahan ajar dalam upaya meningkatkan kualitas proses pembelajaran dan hasil belajar siswa.
\end{abstract}

Kata Kunci: Penelitian Pengembangan, e-Modul Akuntansi

\begin{abstract}
This study aims to produce teaching materials e-Module Accounting basic competencies to record transactions in the basic equation accounting in Vocational High Schools in Palembang that are valid and practical, and to determine their potential effects on student learning outcomes. The research method used is the development research method with the Rowntree Model product development model, while the product evaluation uses the Tessmer formative evaluation model. Based on this development research, the teaching material developed has met the criteria of validity, practicality and has a potential effect, in this case for students the quality of learning outcomes is very good and activity is very high in each meeting. Teacher's advice, can make this teaching material as an innovation in the learning process to be able to improve students' understanding and learning outcomes; schools, to improve laboratory facilities and facilitate teachers to be able to develop teaching materials to improve the quality of the learning process and student learning outcomes.
\end{abstract}

Keywords: Research Development, e-Module Accounting. 


\section{PENDAHULUAN}

Mata pelajaran akuntansi pada satuan pendidikan Sekolah Menengah Kejuruan (SMK) termasuk ke dalam kelompok mata pelajaran produktif. Pembelajaran akuntansi pada tingkat satuan pendidikan SMK memiliki fungsi untuk mengembangkan pengetahuan, keterampilan, sikap rasional, teliti, jujur, dan bertanggung jawab melalui prosedur pencatatan, penggolongan, pengikhtisaran transaksi keuangan, penyusunan laporan keuangan dan penafsiran perusahaan berdasarkan Standar Akuntansi Keuangan (SAK), (Pusat Kurikulum, Balitbang Depdiknas, 2003:6).

Proses pembelajaran akuntansi untuk SMK lebih ditekankan kepada penguasaan kompetensi pembelajaran akuntansi secara utuh dan tuntas. Hal ini disebabkan karena mata pelajaran akuntansi merupakan satu kesatuan siklus pembelajaran yang utuh sehingga keterampilan dan kemampuan yang diharapkan saling berkaitan satu dengan yang lainnya dengan mengutamakan pencapaian melalui pelatihan yang dialami langsung oleh siswa melalui proses pencatatan, pengelompokan, pengikhtisaran dan pelaporan keuangan suatu proses akuntansi. Pada pembelajaran akuntansi di tingkat SMK dimana permasalahan yang timbul timbul yaitu kurang tersedianya sumber belajar mandiri dan jam pelajaran yang kurang pada mata pelajaran akuntansi di sekolah serta penggunaan bahan ajar pembelajaran akuntansi yang bersumber dari penerbit buku ajar akuntansi. Dimana buku ajar dari penerbit lebih memaparkan pelajaran akuntansi secara teoritis atau dapat dikatakan kurangnya penjelasan secara praktis materi ajar ke arah kompetensi pembelajaran terutama pada kompetensi pencatatan transaksi-transaksi akuntansi ke dalam pembukuan-pembukuan akuntansi.

Untuk mengatasi permasalahan tersebut penulis berkeinginan memberikan alternatif pemecahan masalah yaitu dengan mengembangkan sumber pembelajaran mandiri berupa modul yang akan mengarahkan siswa untuk menguasai kompetensi materi ajar akuntansi baik secara teoritis maupun secara praktik. Modul pembelajaran tersebut merupakan salah satu sumber belajar mandiri bagi siswa yang digunakan untuk memudahkan dalam menyalurkan pesan belajar yang ingin disampaikan kepada siswa serta memungkinkan siswa untuk belajar mandiri.

Menurut Purwanto, Rahadi, dan Lasmono (2007: 9), tujuan disusunnya modul ialah agar peserta didik dapat menguasai kompetensi yang diajarkan dalam kegiatan pembelajaran dengan sebaikbaiknya. Modul yang akan dikembangkan peneliti yaitu berupa modul elektronik ( $e$-Modul). Peneliti berkeinginan mengembangkan $e$ - 
Modul salah satunya dikarenakan siswa saat ini sudah banyak yang memiliki dan mampu menggunakan fasilitas elektronik yang bisa untuk membaca modul elektronik (emodul) seperti leptop dan smart phone berbasis Windows, Android, dan $O S$, sehingga memungkinkan siswa untuk belajar dimanapun dengan menggunakan perangkat elektronik tersebut. Dengan adanya bahan ajar berupa $e$-Modul yang terintegrasi langsung dengan kebutuhan belajar siswa khususnya pelajaran akuntansi yang secara langsung akan meningkatkan hasil belajar siswa tersebut.

$e$-Modul Akuntansi dalam penelitian ini dikembangkan berbasis kompetensi berdasarkan kebutuhan siswa SMK Jurusan Akuntansi kelas $\mathrm{X}$ semeter 1 pada mata pelajaran akuntansi dengan implementasi sebagai bahan belajar mandiri di luar jam pelajaran di sekolah. e-modul yang akan dikembangkan diharapkan dapat membantu siswa dalam memahami pembelajaran akuntansi berupa konsep dasar pencatatan akuntansi serta dapat meningkatkan hasil belajarnya.

Beberapa penelitian tentang pengembangan penggunaan $e$-Modul telah dilakukan, antara lain oleh: Pradana, dan Arief (2012) dengan judul, Pengembangan $e$-module Mata Pelajaran Kewarganegaraan Untuk Meningkatkan Hasil Belajar Siswa Kelas X di MAN 3 Malang. Dari data penelitian siswa perseorangan, kelompok kecil, dan lapangan hasil yang diperoleh adalah 84,4\%, 83,6\%, $82,4 \%$ sehingga $e$-Module dikatakan valid/layak digunakan dalam pembelajaran. Hasil pre-test dan post-test 1 terjadi peningkatan hasil belajar rata-rata dengan nilai 34 peningkatan nilai terendah 5 dan tertinggi 70. Hasil pre-test dan posttest 2 terjadi peningkatan hasil belajar rata-rata dengan nilai 35,6 dengan peningkatan nilai terendah 5 dan tertinggi 70 . Dengan demikian menurut pencapaian hasil belajar siswa, modul interaktif yang dikembangkan efektif digunakan sebagai media pembelajaran.

Berdasarkan hasil penelitian tersebut, analisis pengembangan $e$ Modul yang akan dilakukan penulis yaitu $e$-Modul Akuntansi untuk siswa SMK jurusan Akuntansi dengan melihat karakteristik siswa yang beragam, serta peningkatan prestasi belajar siswa. $e$-Modul ini selanjutnya akan diujicobakan pada siswa yang mengikuti mata pelajaran akuntansi pada SMK jurusan Akuntansi kelas X semester 1 pada kompetensi dasar menafsirkan persamaan dasar akuntansi. Selanjutnya $e$-Modul Akuntansi akan dievaluasi, dianalisis serta direvisi/dikembangkan untuk mendapatkan hasil yang maksimal. Dengan uraian materi, tahapantahapan pembelajaran yang mudah dipahami, tampilan yang menarik akan memberikan dorongan belajar mandiri kepada siswa dalam belajar, 
sehingga diharapkan nantinya berdampak positif terhadap hasil belajar siswa.

Tujuan penelitian yang menjadi fokus penelitian ini adalah: Bagaimana mengembangkan $e$ Modul pembelajaran akuntansi untuk siswa SMK kelas $\mathrm{X}$ semester 1 yang teruji validitasnya, praktis dan efek potensial $e$-modul terhadap hasil belajar siswa?

\section{METODE PENELITIAN}

Model pengembangan $e$ Modul akuntansi yang akan digunakan pada penelitian ini adalah model Rowntree. Model Rowntree merupakan model yang berorientasi pada produk khususnya untuk memproduksi suatu bahan ajar. Model pengembangan Rowntree yang terdiri dari tiga tahap, yaitu: perencanaan; pengembangan; dan evaluasi.

Untuk tahap evaluasi produk mengacu pada evaluasi formatif (Tessmer \& Martin, 1998:16), yang meliputi evaluasi oleh peneliti, prototyping (reviu ahli, dan satu-satu, dan kelompok kecil), serta uji lapangan.

Pada penelitian ini, validasi dilakukan oleh ahli bidang studi, ahli media, dan ahli desain pembelajaran untuk mendapatkan masukan dari para ahli tersebut tentang ketepatan isi atau materi, media yang digunakan dan desain pembelajaran dari produk e-modul yang dikembangkan. Pengujian kepraktisan dilakukan untuk mengetahui apakah produk yang dikembangkan mudah digunakan oleh pemakai dengan menggunakan agket atau kuesioner kepada siswa. Selanjutnya keefektifan dilihat dari hasil belajar siswa dengan melakukan penilaian kepada siswa melalui tes.

Prosedur dalam penelitian ini mengadaptasi dari model pengembangan Rowntree. Menurut Prawiradilaga (2008:45), model pengembangan ini terdiri dari tiga tahap, yaitu: tahap perencanaan; tahap pengembangan; dan tahap evaluasi, sedangkan untuk melakukan evaluasi produk mengacu pada evaluasi formatif (Tessmer \& Martin 1998).

\section{HASIL DAN PEMBAHASAN}

Pada penelitian ini terdapat tiga tahapan yang dilakukan berdasarkan model pengembangan Rowntree, yaitu: tahap perencanaan, tahap pengembangan, dan tahap evaluasi.

\section{Hasil Tahap Perencanaan}

Kegiatan menyusun bahan ajar $e$-Modul ini dimulai dengan melakukan analisis kebutuhan yang meliputi wawancara dengan teman sejawat, mengidentifikasi kebutuhan pembelajaran, menganalisis karakteristik siswa, menganalisis silabus, serta mengobservasi lingkungan. Selanjutnya dilakukan menetapkan rumusan tujuan pembelajaran yang meliputi 
menentukan Standar Kompetensi, Kompetensi Dasar, menetapkan indikator, dan menyusun materi yang akan dikembangkan.

Adapun hasil analisis pada tahapan perencanaan ini, sebagai berikut:

Wawancara dengan guru mata pelajaran Akuntansi dilakukan untuk mengetahui masalah atau hambatan serta fenomena apa saja yang dihadapi dalam proses kegiatan belajar mengajar. Berdasarkan hasil wawancara dapat disimpulkan siswa kurang optimal dalam belajar akuntansi di sekolah dikarenakan waktu belajar yang relatif singkat dalam memahami konsep pelajaran tersebut, hal ini juga disebabkan oleh belum efektifnya penggunaan media pembelajaran yang menarik minat siswa untuk belajar secara mandiri. Materi disajikan selama ini hanya berdasarkan buku referensi dari penerbit yang juga sangat terbatas. Sehingga dibutuhkan pembelajaran dengan memanfaatkan TIK berupa bahan ajar $e$-Modul Akuntansi.

Menganalisis

Silabus.

Berdasarkan analisis silabus mata pelajaran Akuntansi dikelompokkan dalam mata pelajaran produktif yang terdiri dari berbagai mata pelajaran akuntansi, sehingga materi yang diajarkan terlalu padat, sedangkan waktu pembelajaran cukup singkat sehingga kompetensi yang diharapkan belum maksimal. Kegiatan pembelajaran masih berpusat pada guru.
Menganalisis Karakteritik dan lingkungan Siswa. Analisis karakteristik siswa ini dilakukan dengan tujuan untuk mengetahui kemampuan umum siswa mengenai materi pelajaran menafsirkan rumus persamaan dasar akuntansi. Pengembangan bahan ajar ini memanfaatkan TIK dalam proses pembelajaran siswa secara mandiri, oleh sebab itu pengguna produk harus memiliki kemampuan minimal seperti dapat mengoperasikan komputer.

Rumusan

Tujuan Pembelajaran. Berdasarkan analisis, dirumuskan bahwa tujuan pembelajaran akuntansi kompetensi dasar menjelaskan konsep dasar pencatatan akuntansi sebagai berikut: Menjelaskan definisi persamaan dasar akuntansi, menjelaskan bentukbentuk persamaan dasar akuntansi, menerapkan pencatatam transaksi kedalam persamaan dasar akuntansi, menjelaskan definisi laporan keuangan akuntansi, menjelaskan bentuk-bentuk laporan keuangan akuntansi, dan menerapkan mekanisme pencatatan laporan keuangan akuntansi.

\section{Hasil Tahap Pengembangan}

Pada tahap pengembangan, peneliti mendesain model awal produk bahan ajar e-Modul Akuntansi menggunakan program Adobe Flash yang terdiri dari dua tahap, yaitu: 
Disain kertas. Pada tahap ini peneliti mendisain garis besar isi media (GBIM), jabaran materi (JM), dan naskah.Naskah menjadi bahan narasi yang digunakan untuk isi bahan ajar yang akan ditampilkan. Narasi merupakan penuntun dalam mengembangkan produk bahan ajar e-Modul Akuntansi menggunakan program Adobe Flash. Tahap ini bertujuan untuk memperoleh gambaran tentang bentuk dan apa saja yang akan ditampilkan pada bahan ajar $e$-Modul Akuntansi menggunakan Adobe Flash pada kompetensi dasar menafsirkan rumus persamaan dasar akuntansi. Gambar dalam storyboard merupakan layar dalam disain berbasis kertas yang berisi antara lain video, suara/bunyi, animasi dan gambar.

Disain berbasis komputer. Pada tahap ini desain produk yang telah dibuat dalam storyboard berbasis kertas dituangkan dalam bentuk berbasis komputer. Adapun program yang digunakan untuk disain produk berbasis komputer ini adalah Adobe Flash. Dengan demikian storyboard yang telah dirancang dibuat dalam program Adobe Flash dapat dilihat Tabel 1:

\section{Tabel 1. Desain Berbasis Komputer Bahan Ajar $e$-Modul Akuntansi}

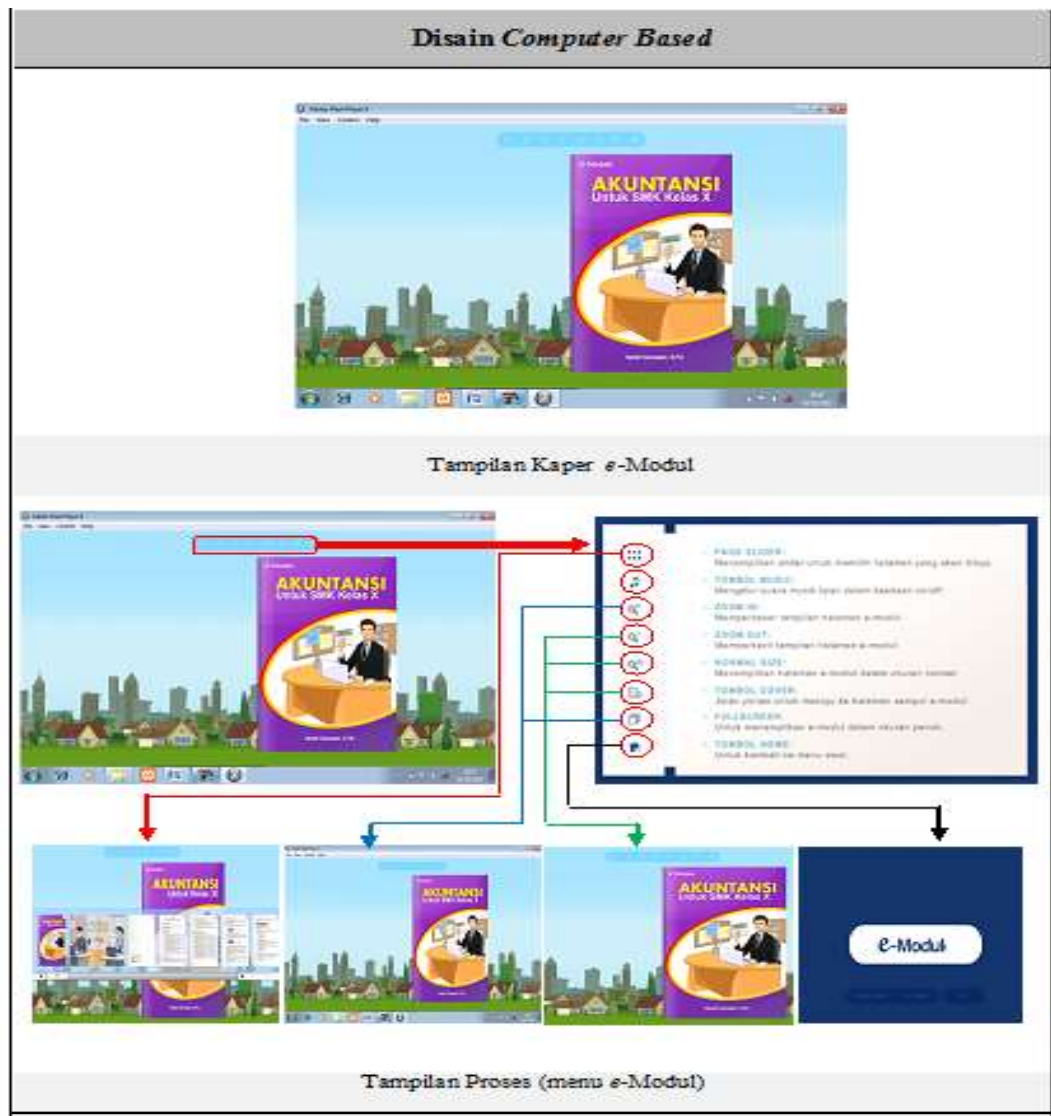

Sumber: Hasil Peneitian 
Tabel 1 di atas adalah desain berbasis komputer dari gambaran naskah pada disain kertas, yang mewakili dari beberapa tampilan materi yang ada di $e$-Modul Akuntansi dengan menggunakan program Adobe Flash dalam bentuk bahan ajar yang dikembangkan oleh peneliti.

\section{Hasil Tahap Evaluasi}

Tahap evaluasi selanjutnya, produk divalidasi oleh pakar (review ahli), uji coba satu satu dan kelompok kecil. Hal ini dilakukan untuk mengetahui validitas dan kepraktisan mengenai bahan ajar yang dikembangkan. Selanjutnya uji coba lapangan adalah uji coba pada subjek penelitian yang sebenarnya di mana hasil dari prototype yang valid dan praktis tersebut akan diuji guna mengetahui efek potensial terhadap hasil belajar siswa.

Hasil tahap evaluasi yang ditampilkan sudah berfokus pada tiga karakteristik utama (isi, instructional, dan media). Isi terdiri dari materi Persamaan dasar akuntansi sesuai dengan Standar Kompetensi. Instructional terdiri dari pembahasan dan keterlaksanaan pengelompokan materi tersusun dengan baik. Media, terdiri dari tampilan pada pengembangan bahan ajar tersebut. Bahan ajar dibuat dengan berbasis kertas berupa naskah materi untuk mempermudah validasi pada tahap awal. Tahap Evaluasi berfokus pada validasi oleh pakar (reviu ahli), uji coba satu satu dan kelompok kecil.

\section{Revisi Ahli}

Pada tahap Reviu Ahli, bahan $e$-Modul Akuntansi kompetensi dasar persamaan dasar akuntansi yang telah didesain oleh peneliti, selanjutnya dilakukan uji validasi oleh pakar yaitu pakar materi akuntansi oleh guru akuntansi, pakar desain pembelajaran oleh dosen desain pembelajaran dan pakar media pembelajaran oleh dosen teknologi dan informasi komputer. Uji validitas ini bertujuan untuk mengetahui kekurangan dari produk $e$-Modul Akuntansi yang dikembangkan. Saran dari validator terhadap bahan ajar $e$-Modul Akuntansi dengan menggunakan program Adobe Flash. Hasil revisi ahli di atas dapat disimpulkan bahwa bahan ajar $e$ Modul Akuntansi menggunakan Adobe Flash dinyatakan layak uji coba sesuai dengan revisi dari para pakar. Tanggapan dan saran dari validator menjadi acuan untuk pengembangan prototype kedua. 
Tabel 2. Tampilan Produk Bahan Ajar e-Modul Akuntansi Sebelum Revisi (Prototype1) dan Sesudah Revisi (Prototype2)

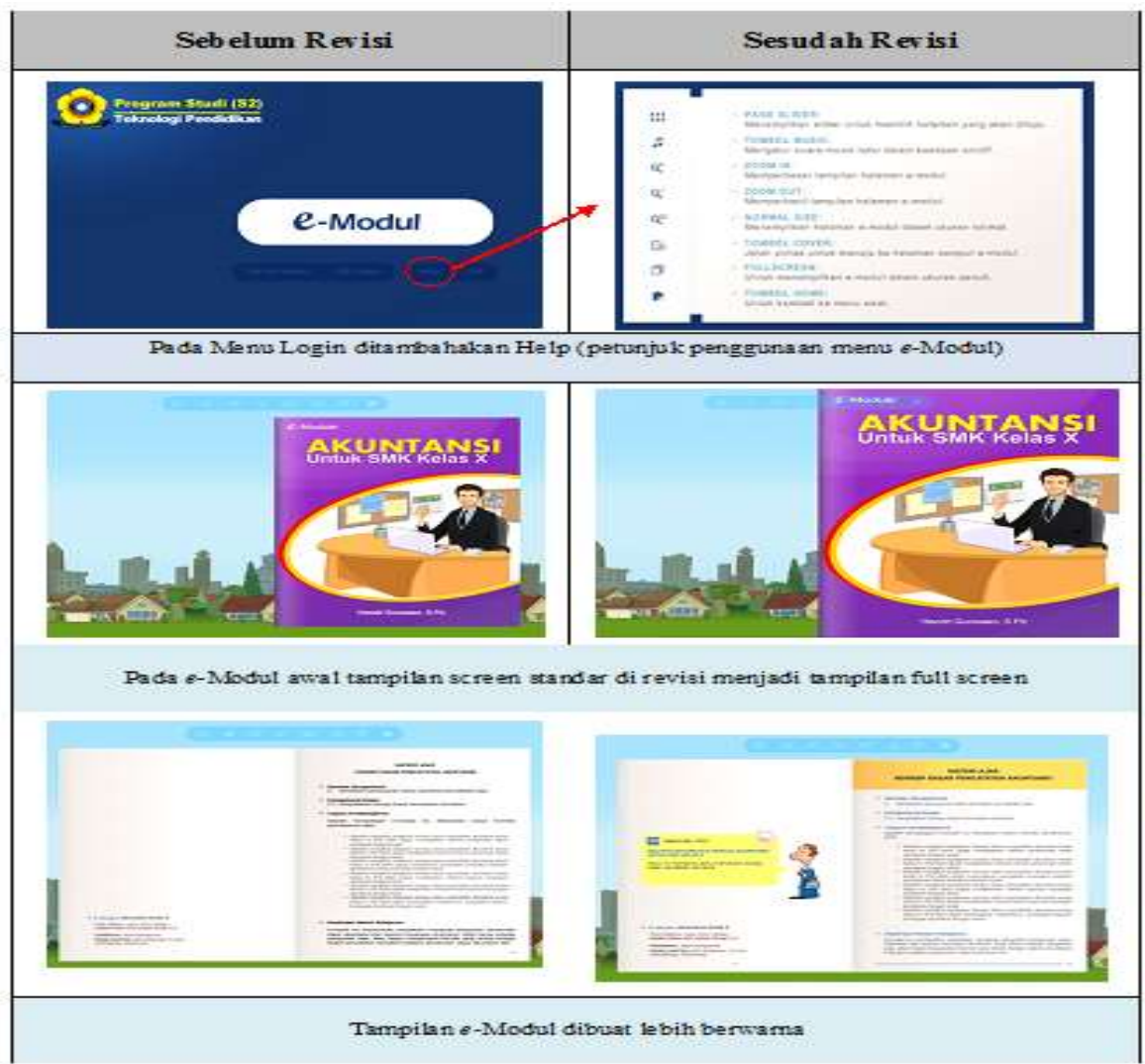

Sumber: Hasil Peneitian

Berdasarkan hasil validasi maka dapat disimpulkan bahan yang dikembangkan tergolong sangat valid dengan rerata $\mathbf{4 , 4 5}$.

Evaluasi Satu Satu. Pada tahap ini produk $e$-Modul Akuntansi diuji cobakan pada satu satu, diuji cobakan pada tiga peserta didik di SMK Negeri 5 Palembang yang memiliki kemampuan rendah, sedang dan di atas rata-rata. Peserta didik belajar menggunakan bahan ajar $e$ Modul Akuntansi, setelah itu peneliti melakukan wawancara dengan peserta didik untuk memberikan komentar atau saran terhadap bahan ajar yang telah dikembangkan. Berdasarkan hasil komentar 3 orang peserta didik yang terlibat dalam uji coba satu satu, dapat ditarik kesimpulan bahan ajar $e$-Modul Akuntansi dapat menarik minat siswa untuk belajar.

Ujicoba Kelompok Kecil. Selanjutnya produk $e$-Modul Akuntansi yang telah direvisi diuji cobakan pada kelompok kecil, yang dilakukan pada siswa kelas $\mathrm{X}$ Akuntansi yang berjumlah 8 orang siswa. Tahap kelompok kecil ini bertujuan untuk melihat kepraktisan bahan ajar yang dikembangkan. 
Proses pembelajaran dengan bahan ajar $e$-Modul Akuntansi dilakukan menggunakan labtop siswa. Hasil angket pengamatan pada siswa kelompok kecil menunjukkan bahwa diperoleh rerata hasil angket peserta didik terhadap bahan ajar $e$-Modul Akuntansi sebesar 100 dengan kategori sangat praktis. Dari rerata hasil angket dapat disimpulkan bahwa prototype ketiga yang dikembangkan oleh peneliti telah memenuhi kriteria kualitas kepraktisan, dilihat dalam uji coba kelompok kecil.

Uji Lapangan. Setelah diperoleh produk $e$-Modul Akuntansi yang valid dan praktis, maka dilakukan uji coba lapangan dengan jumlah siswa 23 orang. Hal ini dilakukan untuk melihat sejauh mana keefektifan bahan ajar $e$-Modul Akuntansi terhadap hasil belajar dan aktifitas siswa. Adapun Kegiatan pembelajaran menggunakan $e$-Modul Akuntansi dilakukan sebanyak 2 kali pertemuan. Pembelajaran yang digunakan berfokus pada siswa, guru hanya bertindak sebagai fasilitator. Pada pertemuan pembelajaran dilakukan observasi untuk mengetahui aktivitas belajar siswa.

Pada pertemuan pertama sebelum membahas materi pembelajaran diawali dengan tes awal. Tes awal ini dilakukan untuk mengukur sejauh mana kemampuan atau pengetahuan siswa. Hasil tes awal didapat $21,73 \%$ dengan kategori baik, kategori cukup yaitu sebesar 34,78\%, kategori kurang yaitu $34,78 \%$ dan $8,69 \%$ kategori amat kurang.

Observasi pada tahap uji lapangan dilakukan pada saat pembelajaran berlangsung yaitu pertemuan pertama dan kedua, observasi ini dilakukan untuk mengetahui tingkat keaktifan siswa dalam kegiatan belajar oleh Dra. Hj. Khoiriah, M.Pd yaitu guru matapelajaran akuntansi.

Data hasil observasi selama pembelajaran pada pertemuan 1dan 2 didapatkan nilai $76,08 \%$ dengan kategori sangat aktif dan $23,91 \%$ dengan kategori aktif.

Diakhir pembelajaran siswa diberikan tes akhir untuk mengukur efek potensial setelah menggunakan bahan ajar $e$-Modul Akuntansi. Adapun hasil tes akhir siswa sebanyak 23 orang siswa dapat dilihat pada tabel 8 berikut ini:

Dari hasil belajar siswa didapat $73,91 \%$ dengan kategori sangat baik, kategori baik yaitu sebesar 8,69\% sedangkan kategori cukup yaitu 17,39\%. Jika dibuat dalam persentase hasil belajar maka dapat disajikan pada gambar 2 sebagai berikut:

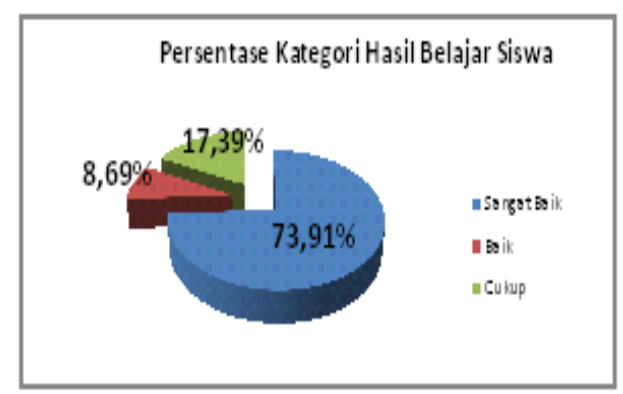

Gambar 1. Presentase hasil belajar sissva (Post test) 
Dari tabel hasil tes awal menunjukkan nilai rerata yang dicapai siswa adalah 68,82 dengan kategori kurang, sedangkan hasil tes akhir siswa diperoleh nilai 91,21 dengan kategori amat baik. Jika nilai tes akhir siswa satu per satu dibandingan dengan nilai KKM akauntansi yaitu 80, dapat diketahui ada 4 siswa yang belum mencapai KKM, masih ada siswa yang mendapatkan nilai di bawah KKM dengan kategori cukup. Dilihat dari perbandingan rerata nilai siswa pada tes awal sebesar 68,82 dan tes akhir sebesar 91,21 artinya terjadi peningkatan sebesar $22,39 \%$. Hal ini menunjukkan bahwa efek potensial dari bahan $e$-Modul Akuntansi ajar yang dikembangkan baik terhadap hasil belajar peserta didik dengan ketuntasan belajar peserta didik sebesar $90 \%$. Berdasarkan uraian di atas, maka dapat disimpulkan bahwa bahan ajar $e$-Modul Akuntansi yang dikembangkan telah memiliki efek potensial terhadap hasil belajar siswa.

\section{Pembahasan}

Penelitian ini menghasilkan bahan ajar $e$-Modul Akuntansi menggunakan program Adobe Flash kompetensi dasar menerapkan konsep dasar pencatatan akuntansi. Pada tahapan pengembangan pertama peneliti mendisaian bahan ajar di atas kertas. Disain berbasis kertas ini berbentuk penjelasanpenjelasan singkat yang terkait dengan materi bahan ajar yang disesuaikan dengan Modul akuntansi yang akan dikembangkan ke dalam $e$-Modul Akuntansi. Hasil disain berbasis kertas, dibuat dalam bentuk disain berbasis komputer.

Dari hasil analisis validasi terhadap isi, desain pembelajaran dan media oleh validator menunjukkan bahwa validitas bahan ajar $e$-Modul Akuntansi diperoleh nilai $4,45 \%$ dengan kriteria sangat valid. Jadi dapat disimpulkan bahan ajar yang dikembangkan dinyatakan sangat valid dan dapat digunakan.

Praktikalitas diperoleh dari uji coba pada satu satu dan kelompok kecil. Tahap uji coba satu satu yang dilakukan terhadap 3 orang siswa, diketahui hasil wawancara dengan siswa terhadap bahan ajar $e$-Modul Akuntansi yang dikembangkan dapat disimpulkan bahwa bahan ajar yang dikembangkan dapat menarik minat siswa dan mudah digunakan. Sedangkan pada uji coba kelompok kecil pada 8 orang siswa didapat hasil rerata angket penilaian sikap siswa terhadap bahan ajar $e$-Modul Akuntansi sebesar 100 dengan kategori sangat praktis. Berdasarkan satu satu dan kelompok kecil terdapat aktifitas dan hasil belajar siswa menunjukkan bahan $e$-Modul Akuntansi menggunakan program Adobe Flash dinyatakan telah praktis.

Efektifitas bahan ajar $e$-Modul Akuntansi ditunjukkan dari hasil belajar 23 siswa, yang mana 17 
orang siswa mendapat nilai di atas $\geq$ 90 (sangat baik) dengan persentase $73,91 \%, 2$ orang siswa mendapat nilai di bawah 90, yaitu 2 orang siswa dengan kategori baik $(8,69 \%)$, dan 4 orang siswa dengan kategori cukup $(17,39 \%)$. Selama kegiatan pembelajaran dengan 2 kali pertemuan dilakukan observasi, adapun hasil observasinya didapati persentase keaktifan siswa yaitu sebesar 76,08\% dengan kategori sangat aktif dan $23,91 \%$ dengan kategori aktif.

Berdasarkan hasil belajar siswa dan observasi pada uji lapangan dapat disimpulkan bahwa bahan ajar $e$-Modul Akuntansi yang diuji cobakan kepada siswa kelas $\mathrm{X}$ Akuntansi di SMK Negeri 5 Palembang dinyatakan efektif. Analisis data di atas menunjukkan hasil yang dapat dipercaya guna menghubungkannya dengan teoriteori yang sudah ada. Sesuai dengan pendapat Azhar (2003:26) yang menyatakan media pembelajaran memiliki beberapa manfaat di antaranya adalah dapat meningkatkan dan mengarahkan perhatian anak sehingga dapat menimbulkan motivasi belajar. Sedangkan Sardiman (2000:5) berpendapat bahwa alat bantu belajar sangat membantu proses pembelajaran dan meningkatkan hasil belajar siswa.

Kedua pendapat tersebut sesuai dengan hasil penelitian pengembangan bahan ajar $e$-Modul
Akuntansi yang peneliti lakukan terhadap hasil belajar siswa. Hasil belajar siswa cenderung lebih tinggi setelah mendapat perlakuan dengan menggunakan $e$-modul akuntansi dengan menggunakan program Adobe Flash dalam proses pembelajaran akuntansi kompetensi dasar menerapkan konsep dasar pencatatan akuntansi.

Selain itu dalam penelitian pengembangan bahan ajar $e$-Modul Akuntansi juga mengalami beberapa kelemahan / keterbatasan menurut peneliti. Dari segi tampilan media pembelajaran yang telah dibuat sudah cukup baik namun masih diperlukan perbaikan, seperti tampilan animasi yang digunakan masih sederhana dan waktu pembuatan yang terbatas. Isi yang terdapat dalam media bahan ajar $e$ Modul Akuntansi masih terbatas pada sub materi, padahal dalam Kurikulum 2013 masih terdapat beberapa materi lain. Oleh sebab itu masih perlu dibuat lebih banyak lagi bahan ajar berbasis komputer, yang tidak hanya untuk mata pelajaran akuntansi, namun apabila perlu semua mata pelajaran akuntansi juga dibuatkan bahan ajar yang sama.

\section{KESIMPULAN}

Berdasarkan hasil penelitian, maka dapat disimpulkan sebagai berikut:

1. Bahan ajar $e$-Modul Akuntansi yang dikembangkan dengan menggunakan program Adobe

Pengembangan E-Modul Akuntansi Kompetensi Dasar Mencatat Transaksi dalam............(Hendri Gunawan) 
Flash pada kompetensi dasar pencatatan transaksi dalam persamaan dasar akuntansi untuk pembelajaran siswa program akuntansi Sekolah Menengah Kejuruan sudah memenuhi kriteria sangat valid menurut validator, berdasarkan isi, bentuk dan susunan.

2. Ditinjau dari isi kepraktisan bahan ajar $e$-Modul Akuntansi yang dikembangkan pada kompetensi dasar menerapkan konsep dasar pencatatan akuntansi telah dinyatakan praktis. Hal ini terlihat dari hasil uji coba satu satu dan keloompok kecil. Pada uji coba satu satu diperoleh hasil wawancara dapat disimpulkan bahwa bahan ajar yang dikembangkan dapat menarik minat siswa dan mudah digunakan. Sedangkan pada kelompok kecil diperoleh hasil rerata angket penilaian sikap siswa terhadap bahan ajar $e$ Modul Akuntansi diperoleh nilai 100 dengan kategori sangat praktis.

3. Hasil uji lapangan menunjukkan bahan ajar $e$-Modul Akuntansi yang dikembangkan untuk pembelajaran Sekolah Menengah Kejuruan program keahlian akuntansi memiliki efek potensial terhadap hasil belajar siswa dan peningkatan aktivitas belajar sisw. Hal ini terlihat dari pencapaian nilai akhir siswa yaitu $73,91 \%$ dengan kategori sangat baik dan
$8,69 \%$ kategori baik serta $17,39 \%$ kategori nilai cukup. Selama kegiatan pembelajaran juga dilakukan observasi. Hasil observasi pertemuan uji lapangan pertama dan kedua yaitu $76,08 \%$ dengan kategori sangat aktif dan 23,91\% dengan kategori aktif.

Berdasarkan hasil penelitian dan kesimpulan di atas, maka saran yang diusulkan peneliti adalah:

1. Siswa, dapat menggunakan bahan ajar $e$-Modul Akuntansi yang dikembangkan dalam pembelajaran baik pada saat jam pelajaran maupun di luar jam pelajaran, agar dapat meningkatkan hasil belajar siswa.

2. Guru, sebagai media dan sekaligus sumber belajar dapat memberikan sumber materi pelajaran yang tidak hanya terbatas pada satu sumber belajar saja. Serta dapat menjadikan bahan ajar $e$-Modul Akuntansi di Sekolah Menengah Kejuruan sebagai inovasi baru dalam proses pembelajaran yang dapat membantu meningkatkan pemahaman dan hasil belajar siswa.

3. Sekolah, dalam usaha meningkatkan hasil belajar siswa yang lebih baik dapat memfasilitasi guru-guru untuk menggunakan berbagai sumber belajar serta mengembangkan bahan ajar yang lebih inovativ dalam pembelajaran di sekolah 
termasuk pemanfaatan $e$-Modul Akuntansi, dalam upaya meningkatkan kualitas proses pembelajaran dan hasil belajar siswa.

4. Peneliti berikutnya dapat mengembangkan bahan ajar dengan media pembelajaran yang lebih inovativ, kreatif dan animasi-animasi yang digunakan lebih baik lagi karena penelitian ini masih sederhana selain itu diharapkan melakukan tes awal untuk melihat efek potensial terhadap media yang dikembangkan sebelum dan setelah menggunakan media tersebut.

\section{DAFTAR PUSTAKA}

Azhar, A. (2003). Media Pembelajaran. Jakarta: Raja Grafindo Persada

Dajamara. (2004). Belajar dan Pembelajaran. Jakarta: Raja Grafindo.

Depdiknas. (2012). Standar Kompetensi Mata Pelajaran Akuntansi Sekolah Menengah Kejuruan. Jakarta: Pusat Kurikulum, Balitbang Depdiknas.

Dick, W. \& Carey, L. \& Carey, J. (1985). The Systematic Design Of Instrruction, (5th ed). New York, NY: Longman.

Djaali \& Muljono, (2008). Pengukuran dalam Bidang Pendidikan. Jakarta: PT. Grasindo.

Khadijah, N. (2009). Psikologi Pendidikan. Palembang: Grafika Telindo Press.
Miarso. Y. (2009). Menyemai Benih Teknologi Pendidikan. Jakarta: CV Rajawali.

Mc Ashan, H. (1989), Competency Based Education : A Process for the improvement of education. New Jersey, NJ: Englewood Cliffs.

Philipus, E. (2008). 1st Step To Be A Designer Flash. Jakarta: Yescom

Pradana \& Arief. (2012). Pengembangan E-Modul Mata Pelajaran Kewarganegaraan Untuk Meningkatkan Hasil Belajar Siswa Kelas X di MAN 3 Malang. Skripsi, Jurusan Teknologi Pendidikan FIP Universitas Negeri Malang.

Purwanto, Rahadi \& Lasmono. (2007). Pengembangan Modul. Jakarta: Pusat Teknologi Informasi dan Komunikasi Pendidikan (PUSTEKOM).

Sardiman AM. (2000) Interaksi dan Motivasi Belajar Mengajar. Jakarta: PT Raja Grafindo Persada.

Tesmer, \& Martin. (1998). The Panning and Conduting Formative Evaluation. Kogan Page. London

Universitas Terbuka. (2002). Pemebelajaran dengan Modul. http:// pustaka.ut.ac.id/ puslata/online.php? menu=bmpshort detail $2 \& I D=3$. Diakses tanggal 12 Februari 2013 